\title{
RELATIONSHIP AMONG SOCIAL MEDIA USES, INTERNET MEDIATION AND POLITICAL PARTICIPATION IN PAKISTAN
}

\author{
Munham Shehzad ${ }^{1 *}$, Arshad Ali $^{2}$, Syed Muhammad Bilal Shah ${ }^{3}$
}

${ }^{1 *}$ FM Manager, Centre for Media and Communication Studies, University of Gujrat, Pakistan; ${ }^{2}$ Assistant Professor, Centre for Media and Communication Studies, University of Gujrat, Pakistan; ${ }^{3} \mathrm{Ph} . \mathrm{D}$. Scholar, Centre for Media and Communication Studies, University of Gujrat, Pakistan.

Email: ${ }^{1 *}$ munhamshehzad10@gmail.com, ${ }^{2}$ arshad.ali@uog.edu.pk, ${ }^{3}$ syedbilal@iiu.edu.pk

\section{Article History: Received on $25^{\text {th }}$ February 2021, Revised on $10^{\text {th }}$ March 2021, Published on $15^{\text {th }}$ March 2021}

\begin{abstract}
Purpose of the study: This study explores the relationship between internet connectivity, social media usage, and political participation. Besides, assess the connection between political participation and vote casting behaviour on social media.

Methodology: The researchers used the Uses and Gratification theory and adopted a quantitative method to collect people's views. A designed questionnaire disseminates among 375 male and female Gujrat and Chi-Square analyses conducted on respondents' data.

Main Findings: The study's demographic findings reveal that most of the respondents belong to age 18-30 with BA/MA education. Students with single marital status use Facebook most of the time to get political information. The study results reveal that those who use social media platforms actively participate in political activities.

Applications of this study: Pakistani people frequently use social media applications like Facebook and Twitter daily to discuss political information. Active social media participants play an important role in political activities and provoke others to participate in the voting process.

Novelty/Originality of this study: Investigating the function of information technology in political practice will reinforce new democratic processes in economically developing countries such as Pakistan. The democratic system in Pakistan is not robust. Social media is experimenting with voter self-promotion and mobilisation to influence voters to change power dynamics in a politically motivated way.
\end{abstract}

Keywords: Social Media, Internet, Political Participation, Political Communication, Political Affiliation.

\section{INTRODUCTION}

Over the last two decades, information and communication technology has changed rapidly, with significant developments in social media and mobile technology (Adegbola\& Gearhart, 2019). Social networking sites and applications recognised as useful and influential tool for learning political issues and behaviour (Valenzuela et al., 2019). As they not only facilitate the sharing of information but also provide a variety of ways to communicate. The backbone of social media is the profile and friend list displayed. However, social media's most familiar user activities are to read and reply to messages, posts, comments, friend profiles, and official pages (Ellison et al., 2007).

In contrast, social networking sites affect daily discussions about political issues online and offline (Hampton et al., 2017). Social media is one of the fastest and targeted platforms for people where they interact with others. Despite the growing popularity of social media these days, it is not as novel as initially. Growing literary organisations from outside the United States point out that social media campaigns are undoubtedly a global trend (Jacobs \& Spierings, 2016). Besides, Facebook, Twitter, and Google actively shape campaign communication through close collaboration with political staff (Kreiss \& McGregor, 2018).

Many global events, such as the Arab Spring and the Wall Street movement, justify social media's political scope (Howard \& Hussain, 2013; Penney \& Dadas, 2014). Such incidents show that social media's advent has inevitably changed the political culture (Shao \& Wang, 2017). Extensive media platforms and enhancement of key innovations in new media technologies do not rule out the need for physical intimacy. Posts of political leaders on social media provoke their followers to like, share, or comment on and participate in the political discussion (Goh et al., 2018). Most U.S. political campaigns use social media as part of a broader communication strategy. Social media campaigns typically used through forced interactivity, thinking that seeks to influence online public behaviour to select candidates (Freelon, 2017). Spokespersons believe that social media helps organisations communicate with and build relationships with the public in an open, fast, and inexpensive way (Graham \& Avery, 2013; Theunissen \& Noordin, 2012), whereas politicians use Facebook and Twitter for political purposes (Stier et al., 2018). In other words, social media has proven to be very useful for communication between any organisations, privately or publically. Besides, SNS is "high" popularity, low cost, relatively easy to use, and can reach many users.

In the political culture, political organisations or leaders use social media networks to maintain beneficial relationships with active people (Linde \& Peters, 2020). Social networking sites are increasingly used for political activities (Liu et al., 2017), media Trust and support are prerequisites for active citizenship. The use of social media in politics has 
increased in recent years. Many countries and political leaders worldwide used social media platforms to provoke people to participate in the political process after the Barack Obama world record in the 2008 U.S. presidential election using social media for political purposes (Madueke et al., 2017). Social media is where most young people get political news, knowledge and discuss political issues. Therefore, social media, the source of political dialogue, is the best platform for attracting potential voters and turning them into dedicated voters. With social media's help, the general public can become a compelling agent and take advantage of personal networks for their favorite values, positions, or ideological postures. Mobilisation saw how contestants, political parties, campaigners, and groups force others to participate in the political process to win elections, pass bills, and influence policy (Aleyomi \& Olanrewaju, 2014). This political culture change has fuelled political debate on social media (Miller et al., 2015). The use of social media has increased political communication (Nulty et al., 2016), political support candidates (Groshek, 2017), and online political association (Kim \& Chen, 2016).

In a modern democracy, governments use social media to engage citizens in decision-making, and civil society can involve people in specific issues. Quality information on social media increases people's trust in political candidates or parties (Arshad \& Khurram, 2020). Social media is a powerful force in social engineering and political campaigns, which is partner-friendly, interactive, and cost-effective (Spierings \& Jacobs, 2019). Many researchers have studied persuasion as a predecessor to various social behaviours, such as political behaviour, consumer behaviour, and psychological behaviour (Gillespie \& Joireman, 2016; Wyer, 2010). Political persuasion is a binding political instrument used by dictatorships and stakeholders to attain preferred consequences. In guiding the agenda, it is essential to review them through social media during the free election period. It plays an essential role in building and maintaining political institutions to restore and destroy democratic processes in all social and political settings (Ahmad, 2020). Political persuasion and political association is a fundamental gauge of the political, voting, and elected procedure. Investigating information technology's political practice function will reinforce new democratic processes in economically developing countries such as Pakistan. In Pakistan, social media is experimenting with voter self-promotion and mobilisation to influence voters to change power dynamics in a politically motivated way. In addition to these studies, there is a lack of literature on social media marketing platforms in political participation (Ahmed \& Skoric, 2015; Ahmad et al., 2016). Social media is a marketing tool where people, companies, governments, and political candidates introduce their products, ideas, and policies to disseminate. This research will cover the gap and provide a comprehensive study on the participation and involvement in political activities through social media as a political tool in Gujrat city, Pakistan.

RQ1: Whether internet connection leads to political affiliation.

RQ2: Whether social media usage leads to political persuasion.

RQ3: Whether political activities on social media lead to political participation.

RQ4: Whether political participation in social media leads to casting a vote.

\section{LITERATURE REVIEW}

Omotayo and Folorunso (2020) researched the use of social media for political participation by youths in Oyo State, Nigeria, the types of social media, types of political activities, and factors that influence the use of social media for political participation. The researchers collected data from 322 three Nigerian universities through a structured questionnaire. The findings of the study show that social media play an essential role in political participation. Most youths use Facebook, Whatsapp, Instagram, Twitter, and Yahoo messenger for political activities, advocacy, campaigns, and discussion with political leaders, lobbying, and electoral misconducts. The growing popularity and diffusion of social media in people's lives play an essential role in mobilising youth for political participation. Active involvement in political activities on social media provokes people to participate in the political process (Apuke \& Tunca, 2018); most youth use Facebook for political activities due to low cost and efforts (Orfan, 2020). Youth worldwide use social media outlets to get political information (Yamamoto et al., 2020) and are more likely to react to political content (Jeroense et al., 2021).

Ida et al. (2020) researched the relationship between social media and youth involvement in political learning, participation, and efficacy. They collected data from Pakistan and Indonesia through online and offline surveys. Findings of the study show that social media enhance youth participation in political activities, which leads to political knowledge and political efficacy. Youth actively participate in political matters on social media and sensitise people to engage themselves in political discussion. Adegbola and Gearhart (2019) researched the relationship between social media and political engagement in the USA, Kenya, and Nigeria through secondary data collected by Pew researchers from 1775 respondents. The results point out the difference between traditional and new media use on political involvement between countries and media use as a precursor to political involvement. In particular, access to news from social media and online news platforms was associated with high political participation levels in all three countries. Therefore, these studies show that social media redefines Nigeria's political communication, leading to a significant shift to this technology's use in the election process. Many researchers investigated social media news's influence on people's political participation (Abdulrauf, 2016; Onyechi, 2018), where active Twitter users actively participate in the voting process (Mousavi \& Gu, 2019). 
Lappas et al. (2021) Researched to investigate the relationship between social media content and citizen's engagement, along with the impact of dialogic communication. They examined the facebook content of five Greek municipalities. The study findings reveal that conversational posts and posts that trigger offline engagement activities significantly impact all forms of online engagement for these citizens. Local government social media managers in Greece post rich media content on Facebook in videos and posts to motivate citizens to participate in various offline activities. Political digital media literature suggests a positive link between Internet use and political participation (Kim \& Lee, 2019); easy access to political information on social media significantly relates to a high political participation level (Ohme, 2019). Social media users access political news actively (Karakaya \& Glazier, 2019), and social networking users are young and more ethnically diverse (Bossetta, 2018).

Halpern and Katz (2017) researched the social media influence on political participation through collective and internal efficacy. This study provides a theoretical model based on collective and internal usefulness to explain the different ways in which political involvement on Facebook and Twitter can influence individuals and engage in political activity. The researchers conducted a panel survey among adults, tested the Chile model in 2013, and found that regular use of Facebook and Twitter to share political information leads to high participation levels through various utility initiatives. Facebook has a strong influence on the collective efficacy of the users but not on internal efficacy. On the other hand, Twitter has an influence on internal efficacy but not on collective efficacy. Facebook and Twitter are the essential tools for political activities worked as "double-barreled gun" (Jacobs et al., 2020). Social media usage for political participation encourages people to vote for given candidates or parties (Kasadha, 2019). Social media usage affects political participation at large (Boulianne, 2019), a strong relationship between interpersonal communication and citizen engagement ( Shah et al., 2005), and network size enhances user's interaction with the latest information political active users (Huckfeldt et al., 2004).

Keating and Melis (2017) researched the impact of social media on youth political engagement. They use a latent class analysis web survey and collect data from young Britons aged 22-19. The study's findings reveal that social media provides new platforms for new young adults but not re-engaging the adults who lost their interest in politics. Social media offers a unique opportunity to represent voter statistics. Numerous analogy techniques have proven the increasing number of voters, and they are especially suitable for social media platforms. YouthSocial pressure messages usually emphasise the nature of open ballot records and consist of postcard mailers that include articles and neighbors' past dates of participation (Gerber et al., 2010). Social pressure works by raising awareness of individual voting compliance, and Facebook exposes users' behaviour within the network, a social networking platform for delivering these messages increase the voting turnout. Besides, direct voter involvement in campaigning or telephone banking can be beneficial (Green \& Gerber, 2015). Mahmud \& Amin (2017) carried out research and investigated that college students focused on using online media in political activities. The results of this survey highlight the relationship between online and offline political participation. However, compared to Facebook, email plays a small role in political debate. Schmiemann (2015) investigated social networking sites and political participation relationships and accomplished that the content of Facebook had a positive reaction to political participation. In contrast, Gibson and McAllister (2012) assess online social relationships and political involvement and looked at how online platforms enhance political interaction. Additionally, online connections between unrelated pull networks facilitate similar relationships and found that online social networking encourages offline participation.

\section{THEORETICAL FRAMEWORK}

The propagation of the latest communication technologies might affect communication arrangements in society and offer a wide range of options to meet communication needs. Social media became an active platform for researchers, marketers, students, celebrities, and many other economic, social, and political organisations. Today, millions of people engage in social media activities that allow them to search for their favorite topics at any time and whatever they like (Bicen \& Cavus, 2010; Papoola, 2014). With the spread of the internet and the expansion of social media platforms, Whiting \& Williams (2013) claimed that people knew a little about why and how to use social media, which is the bottom line of uses and gratification theory. Uses and gratification theory provides ways to identify and analyse why people use social media (Kim et al., 2013). Unlike traditional media, which gives users limited choices, this new media offers new options, and this theory helps to define users' needs and achieved gratifications (Matei, 2010).

Social media is a two-way communication process where users gratify their needs, uses and gratification theory is an effective and large-scale platform for this engagement (Joinson, 2008; Ko et al., 2005). Young people use social media to get the latest news and information (Sheldon, 2008). Participation in political activities enables young people to use social media (Roy, 2009), and they use social media online and offline to gratify their political participation needs (Park et al., 2009). The uses and gratification examine how and why people use media (Stafford et al., 2004). The theory of uses and gratification did not worry about what the media do with the people, but revealed what people do with media, while users influence the media; they have increasingly contributed to understanding the role of the media in their lives and use to gratify their needs (Anaeto et al., 2008). New media users are very active, and they have their own needs and are exposed through selected media messages. However, positive media messages remain for users' satisfaction (Adeyanju\& Haruna, 2012). The uses and gratification reveal that people play a significant role in the communication process when people select, interpret, and act on content (Akinwunmi, 2011). Scholars believe that traditional models 
provide a practical framework for studying the internet and new media communications through uses' and gratification (Kuehn, 1994; Morris \& Venkatesh, 2000).

\section{METHOD}

In this study, the researchers used a cross-sectional design. They used a purposive sampling method to collect data from 375 male and females respondents of Gujrat city, Pakistan, through a structured questionnaire. Ahmad's (2020) scale was borrowed for this study. The questionnaire uses items based on Likert-scale ranging from ( $5=$ Always to $1=$ Never). The questionnaire consists of two parts: first demographic variables, and second, a 14-item measure related to political activities on social media. The demographic variables include gender, age, education, profession, and marital status, including internet connectivity, political affiliation, social media usage, and daily time spent on social media, social media applications, and the purpose of using social media. The reliability of the scale for this study was found to be 0.77 .

Table 1: Demographic Variables

\begin{tabular}{lll}
\hline Demographic & Variables & Frequency(\%) \\
\hline \multirow{3}{*}{ Age } & $18-30$ & $64.9 \%$ \\
\cline { 2 - 3 } & $31-45$ & $16.9 \%$ \\
\cline { 2 - 3 } Gender & $46-60$ & $18.3 \%$ \\
\hline \multirow{3}{*}{ Education } & Male & $57.1 \%$ \\
\cline { 2 - 3 } & Female & $42.9 \%$ \\
\cline { 2 - 3 } & Metric & $35.1 \%$ \\
\cline { 2 - 3 } & Intermediate & $12.0 \%$ \\
\cline { 2 - 3 } Profession & M.PhilorAbove & $16.9 \%$ \\
\cline { 2 - 3 } & Working & $40.3 \%$ \\
\cline { 2 - 3 } & Student & $40.9 \%$ \\
\cline { 2 - 3 } Marital Status & Household & $18.9 \%$ \\
\cline { 2 - 3 } & Single & $63.7 \%$ \\
\cline { 2 - 3 } & Married & $20.0 \%$ \\
\cline { 2 - 3 } & Widow & $7.7 \%$ \\
\cline { 2 - 3 } & Divorced & $8.6 \%$ \\
\hline
\end{tabular}

Demographic table 1 shows that most of the respondents, $57.1 \%$ were male and $42.9 \%$ females. The majority of the respondents, $64.9 \%$, had 18-30 years, $18.3 \%$ belonged to $46-60$, and $16.9 \%$ had $31-45$. Most of the respondents, $36 \%$, had BA/MA education, $35.1 \%$ had metric, $16.9 \%$ M.Phil or above, and $12 \%$ had intermediate education. The majority of the respondents, $40.9 \%$ were students, $40.3 \%$ belong to work, and $18.9 \%$ were household. Most of the respondents, $63.7 \%$, were single, $20 \%$, were married, $8.6 \%$ divorced, and $7.7 \%$ were a widow.

\section{RESULTS AND FINDINGS}

Findings of the study reveal that most male respondents aged 18-30 with BA/MA education participated in the survey to record their views. Most of the respondents were students with single marital status.

Table 2: Descriptive Statistics

\begin{tabular}{lll}
\hline Independent Variables & Frequencies & \\
\hline Internet Connectivity & Yes & $94.6 \%$ \\
\cline { 2 - 3 } & No & $5.4 \%$ \\
\hline \multirow{3}{*}{ political affiliation } & Having no PoliticalAffiliation & $14.9 \%$ \\
\cline { 2 - 3 } Social Media Usage & HavingPoliticalAffiliation & $85.1 \%$ \\
\cline { 2 - 3 } & Rarely & $0.9 \%$ \\
\cline { 2 - 3 } & Occasionally & $9.1 \%$ \\
\cline { 2 - 3 } Frequently & $57.7 \%$ \\
\hline \multirow{3}{*}{ Always } & $32.3 \%$ \\
\cline { 2 - 3 } & 1 or less than 1 hours & $4.6 \%$ \\
\cline { 2 - 3 } & 2 hours & $11.7 \%$ \\
\cline { 2 - 3 } & 3 hours & $20.9 \%$ \\
\cline { 2 - 3 } & 4 hours & $35.7 \%$ \\
\cline { 2 - 3 } Social Media Application & 5 hours and above & $34.1 \%$ \\
\hline & Facebook & $2.9 \%$ \\
\hline
\end{tabular}




\begin{tabular}{lll}
\hline & Whatsapp & $20.9 \%$ \\
\cline { 2 - 3 } & Twitter & $24.6 \%$ \\
\cline { 2 - 3 } Purpose to Use Social Media & All of them & $17.4 \%$ \\
\cline { 2 - 3 } & Politicallnformation & $40.0 \%$ \\
\cline { 2 - 3 } & Entertainment & $9.1 \%$ \\
\cline { 2 - 3 } & Discussion & $9.7 \%$ \\
\cline { 2 - 3 } & Socialisation & $29.1 \%$ \\
\cline { 2 - 3 } & Education & $12.0 \%$ \\
\hline
\end{tabular}

Table 2 shows that the majority of the respondents, 94.6\%, had internet connectivity, and $5.4 \%$ had no internet connectivity. Most of the respondents, $85.1 \%$, had political affiliation, and $14.9 \%$ had no political affiliation. The majority of the respondents, $57.7 \%$, use social media frequently, $32.3 \%$ always use social media, $9.1 \%$ use it occasionally, and $0.9 \%$ rarely use social media. Most of the respondents, $35.7 \%$ spend 4 hours daily, $27.1 \%$ spend 5 hours and above, $20.9 \%$ spend 3 hours, $11.7 \%$ spend 2 hours, and $4.6 \%$ spend 1 or less than 1 hour daily. The majority of the respondents, $34.3 \%$, use the Facebook application, $24.9 \%$ use Twitter, $20.9 \%$ use Whatsapp, $17.4 \%$ use them, and $2.9 \%$ use Instagram. Most of the respondents, $40.0 \%$, use social media for political information, $29.1 \%$ used for socialisation, $12 \%$ use for education, $9.7 \%$ used for discussion, and $9.1 \%$ used for entertainment.

Table 3: Descriptive statistics of political persuasion

\begin{tabular}{ll}
\hline PoliticalPersuasion & Frequency (\%) \\
\hline I engage in political activities on social media & $222(63.4 \%)$ \\
\hline I share political news/events on social media & $206(58.9 \%)$ \\
\hline I share videos/speeches of political parties/leaders & $92(26.3 \%)$ \\
\hline I like political pages on social media to know the current trends and political tendencies & $240(68.6 \%)$ \\
\hline I share my political views on social media & $228(65.1 \%)$ \\
\hline I get interested in the political ideas of other parties on social media & $201(57.4 \%)$ \\
\hline I engage myself in political arguments with my friends & $202(57.7 \%)$ \\
\hline I criticise the policies of the opposite political parties & $209(59.7 \%)$ \\
\hline I urge friends to vote in favour of my political party & $236(67.4 \%)$ \\
\hline I motívate people to cast votes on social media & $234(66.9 \%)$ \\
\hline I justify the ideology/action of my political party & $234(66.9 \%)$ \\
\hline I participate in political conversations to share my opinion/ideas & $241(68.9 \%)$ \\
\hline
\end{tabular}

Table 3 presents the political participation of Pakistani people on social media. The study's findings show that $63.4 \%$ of people frequently engage in political activities; $58.9 \%$ share political news and social media events. Of most respondents, $26.3 \%$ rarely share political leaders' video speeches, $68.6 \%$ of people like political pages to know political trends, and $65.1 \%$ frequently share political views on social media. The majority of the people, $57.4 \%$ get political ideas from other political parties, $57.7 \%$ people engage in political discussions with friends, $59.7 \%$ frequently criticise opponents' policies, and $67.4 \%$ frequently motivate friends to vote in favour of their/her party. Most of the respondents, $66.9 \%$, frequently motivate people to cast their vote, $66.9 \%$ people justify their favorite political party's ideology, and $68.9 \%$ frequently participate in political conversations to share their opinions.

Table 4: Whether internet connection leads to political affiliation

\begin{tabular}{|c|c|c|}
\hline \multicolumn{3}{|l|}{ Chi-Square Tests } \\
\hline & Value Df Asymp. Sig. (2-sided) & Exact Sig. (2-sided) Exact Sig. (1-sided) \\
\hline Pearson Chi-Square & $1.462^{\mathrm{a}} 1 \quad .227$ & \\
\hline Continuity Correction $^{\mathrm{b}}$ & $\begin{array}{lll}.770 & 1 & .380 \\
\end{array}$ & \\
\hline Likelihood Ratio & $\begin{array}{lll}1.847 & 1 & .174 \\
\end{array}$ & \\
\hline Fisher's Exact Test & & .329 \\
\hline \multicolumn{3}{|c|}{$\begin{array}{llll}\text { Linear-by-Linear Association } & 1.458 & 1 & .227\end{array}$} \\
\hline $\mathrm{N}$ of Valid Cases & 350 & \\
\hline \multicolumn{3}{|c|}{ a. 1 cells $(25.0 \%)$ have an expected count of less than 5 . The minimum expected count is 2.82 . } \\
\hline b. Computed only for a $2 \times 2 \mathrm{ta}$ & & \\
\hline
\end{tabular}

This table shows that the $\mathrm{P}$-value $=.195$ is greater than the significant value $=0.05$, indicating an association between the internet connection and political affiliation. 
Table 5: Whether social media usage leads to political persuasion

\begin{tabular}{llll}
\hline Chi-Square Tests & & & \\
\hline & Value & Df & Asymp. Sig. (2-sided) \\
\hline Pearson Chi-Square & $16.349^{\mathrm{a}}$ & 16 & .429 \\
\hline Likelihood Ratio & 16.772 & 16 & .401 \\
\hline Linear-by-Linear Association & 2.815 & 1 & .093 \\
\hline N of Valid Cases & 350 & & \\
\hline
\end{tabular}

a. 5 cells $(20.0 \%)$ have an expected count of less than 5 . The minimum expected count is 1.65 .

This table shows that the $\mathrm{P}$-value $=.429$ is greater than the significant value $=0.05$, which indicates an association between the purpose of social media usage and online political persuasion.

Table 6: Whether political activities on social media lead to political participation

\begin{tabular}{llll}
\hline Chi-Square Tests & & & \\
\hline & Value & Df & Asymp. Sig. (2-sided) \\
\hline Pearson Chi-Square & $17.268^{\mathrm{a}}$ & 16 & .368 \\
\hline Likelihood Ratio & 18.864 & 16 & .276 \\
\hline Linear-by-Linear Association & .101 & 1 & .751 \\
\hline N of Valid Cases & 350 & & \\
\hline a. 13 cells (52.0\%) have an expected count of less than 5. The minimum expected count is .21. \\
\hline
\end{tabular}

This table shows that the $\mathrm{P}$-value $=.368$ is greater than the significant value $=0.05$, which indicates an association between the engagement of political activities on social media and online political persuasion.

Table 7: Whether motivation to cast a vote on social media leads to political persuasion

\begin{tabular}{llll}
\hline Chi-Square Tests & & & \\
\hline & Value & Df & Asymp. Sig. (2-sided) \\
\hline Pearson Chi-Square & $10.973^{\mathrm{a}}$ & 16 & .811 \\
\hline Likelihood Ratio & 13.335 & 16 & .648 \\
\hline Linear-by-Linear Association & .817 & 1 & .366 \\
\hline N of Valid Cases & 350 & & \\
\hline a. 11 cells (44.0\%) have an expected count of less than 5. The minimum expected count is .21. \\
\hline
\end{tabular}

This table shows that the $\mathrm{P}$-value $=.811$ is greater than the significant value $=0.05$, which indicates an association between motivating to cast a vote on social media and online political persuasion.

\section{DISCUSSION}

Social networks support both the restoration of existing social connections and the creation of new social connections. In most preliminary research on online communities, individuals use these systems to connect with other users outside existing social groups or locations to create communities for common interests rather than common areas. Social media is one of the fastest and most targeted platforms for people to interact with others. In the political arena, political groups and leaders use social media networks to maintain and influence beneficial relationships with essential and active people. In recent years, the use of social media in politics has increased. Many countries and political leaders worldwide used social media platforms to engage people in the political process for political purposes. Social media has increased political communication (Nulty et al., 2016), online political involvement, and online political association (Kim \& Chen, 2016). Social media is where most young people get political news and knowledge and discuss political issues. Therefore, social media, the medium of political dialogue, becomes the best platform for attracting potential voters and enthusiastic voters.

Pakistani society is a developing society where most of the population actively participate in political activities and use social media platforms for political discussions. The study's findings show that most of the respondents belong to age between 18-30 years and have BA/MA education. The majority of the respondents were students with single marital status, participated in the survey. Most of the respondents have internet connectivity and frequently use social media applications, and most of them have a political affiliation. The majority of People spend 4 hours on social media and use Facebook daily to get political information for socialisation with friends, family, and community.

In contrast, Twitter is the second usable platform among Pakistan's people. Social media applications are used for political information, education, entertainment, socialisation, and discussion worldwide, but in Pakistan, most of them use social media platforms for political information and socialisation. Currently, 73\% of adults use online Facebook (Smith, 2014), and 66\% of users have already reported at least one civic or political activity on the platform; Facebook 
and Twitter can influence individuals and engage in political activity (Halpern \& Katz, 2017). Many researchers conducted researchers to find a relationship between personal networks and political participation (Huckfeldt et al., 2000), a strong relationship between interpersonal communication and citizen engagement (Shah et al., 2005), and network size enhances users interaction with active political users (Huckfeldt et al., 2004). Halpern and Katz (2017) researched the social media influence on political participation through collective and internal efficacy.

People worldwide used social media applications daily to get knowledge, political discussion, entertainment, socialisation, and education. People of Pakistan use social media applications to participate in political activates, share political news and video speeches. Pakistani society is an amalgam of different people had diverse like/dislikes, behaviour, attitude, and affiliation with religion, political parties, and social norms. People with different political attachments criticise the policies of opponent political parties, share their opinions, justify the ideology of the favorite political party, motivate their friends to vote in favour of his/her party, and motivate them to cast a vote. Many researchers found that people use social media platforms to participate in political activities (Mahmud \& Amin, 2017). Social media content positively relates to political participation (Schmiemann, 2015), and online media platforms enhance political interaction (Gibson \& McAllister, 2012). Many countries and political leaders worldwide used social media platforms to provoke people to participate in the political process. Social media in politics has increased in recent years (Madueke et al., 2017). People, through internet connectivity, get political news from social media, which leads to political participation. Findings of the current study indicate that $\mathrm{P}$-value $=.195$ is greater than the significant values $=$ 0.05 , which shows an association between the internet connection and political affiliation. Many researchers investigated social media news's influence on people's political participation (Abdulrauf, 2016; Onyechi, 2018). Social media has increased political communication (Nulty et al., 2016), online political involvement, and online political association (Kim \& Chen, 2016).

Political persuasion is a binding political instrument used by dictatorships and stakeholders to attain preferred consequences. In guiding the agenda, it is essential to review them through social media during the free election period. It plays an essential role in building and maintaining political institutions to restore and destroy democratic processes in all social and political settings (Ahmad, 2020). The study's findings show that the P-value $=.429$ is greater than the significant value $=0.05$, which indicates the strong association between social media usage and online political persuasion. Political digital media literature suggests a positive link between internet use and political participation, significantly as internet adoption increases among American adults. Many researchers have studied persuasion as a predecessor to various social behaviours, such as political behaviour, consumer behaviour, and psychological behaviour (Gillespie \& Joireman, 2016; Wyer, 2010). Political persuasion and political association is a fundamental gauge of the political, voting, and elected procedure.

Social media is versatile because it acts as a social change tool, but it also tries to stabilise the community as an online political persuasion tool. Social media increased political involvement by allowing citizens to communicate with representatives and peers. The study's findings show that the P-value $=.368$ is greater than the significant value $=0.05$, indicating an association between political activities' engagement on social media and online political persuasion. Many researchers investigated that more active user on social media sites play an active role in political participation and political message dissemination, and interpersonal communication on social media influence political participation (Eveland et al., 2005; Moy \& Gastil, 2006).

The source of political dialogue is the best platform for attracting potential voters and turning them into dedicated voters. The current study indicates that the P-value $=.811$ is greater than the significant value $=0.05$, which shows the association between motivating to cast a vote on social media and online political persuasion. Direct voter involvement in campaigning or telephone banking can be beneficial (Green \& Gerber, 2015). The use of social media as a powerful force in social engineering and political campaigns is increasing. This technology is partner-friendly, interactive, and cost-effective. As far as political communication and participation are concerned, it is at the heart of the moment. Many researchers conducted researchers to find the relationship between personal networks and political participation (Huckfeldt et al., 2000), a strong relationship between interpersonal communication and citizen engagement (Shah et al., 2005). Network size enhances users interaction with the latest information political active users (Huckfeldt et al., 2004), the influence of social media news on the political participation of people (Abdulrauf, 2016; Onyechi, 2018), and the use of social media and political engagement (Adegbola \& Gearhart, 2019).

\section{CONCLUSION}

Around the world, mobile devices dominate in terms of total time spent online. It creates a way for anyone to connect anytime and anywhere. The study results reveal that those who use social media platforms actively participate in political activities. Most of the time, Pakistani people frequently use social media applications like Facebook and Twitter daily to get political information and discussion. Higher exposure to social media leads to high participation in political activities. Compared to other media, the impact of social media on political campaigns is tremendously increasing. Social networks are playing an increasingly important role in electoral politics. Social media allows people to communicate freely with each other; they are once again, helping create a surprisingly influential social organisation for disadvantaged groups. Active social media participants play an important role in political activities and provoke others to 
participate in the voting process. The majority of the Pakistani people, who actively participate in political discussion on social media, actively participate in the voting process.

\section{LIMITATION AND STUDY FORWARD}

This study primarily focused on accessing social media's role in the political process at Gujrat city due to limited resources. In the age of globalisation, social media is playing a significant role to increase political awareness. In the future, this study was carried out in different cities to check the effects of social media on Pakistani people's political participation and voting behaviour.

\section{AUTHORS CONTRIBUTION}

Munham Shehzad (Abstract, Literature Review, Research Questions, Findings).

Arshad Ali (Introduction, Conclusion).

Syed Muhammad Bilal Shah (Data Collection, Text, and Reference Formatting).

\section{REFERENCES}

1. Abdulrauf, A. A. (2016). Cognitive engagement and online political participation on Facebook and Twitter among youths in Nigeria and Malaysia. PhD Thesis, Universiti Utara, Malaysia. Retrieved June 19, 2018 from http://etd.uum.edu.my/6039/2/s95350_02.pdf

2. Adegbola, O., \& Gearhart, S. (2019). Examining the relationship between media use and political engagement: A comparative study among the United States, Kenya, and Nigeria. International Journal of Communication, 13, 1231-1251.Retrieved from https://ijoc.org/index.php/ijoc/article/view/10501

3. Adeyanju \& Haruna (2012). Uses of SMS in campaigns: An assessment of the 2011 general elections and post election violence in northern Nigeria, in Des Wilso (ed.) The media, terrorism \& political communication in Nigeria.Uyo; ACCE.

4. Ahmad, S. (2020). Political behaviour in virtual environment: Role of social media intensity, internet connectivity, and political affiliation in online political persuasion among university students, Journal of Human Behavior in the Social Environment, 30(4), 1-17. https://doi.org/10.1080/10911359.2019.1698485

5. Ahmad, S., Mustafa, M., \& Ullah, A. (2016). Association of demographics, motives and intensity of using Social Networking Sites with the formation of bonding and bridging social capital in Pakistan. Computers in Human Behavior, 57, 107-114. https://doi.org/10.1016/j.chb.2015.12.027

6. Ahmed, S., \& Skoric, M. (2015). Twitter and 2013 Pakistan General Election: The Case of David 2.0 Against Goliaths. In: Boughzala I., Janssen M., Assar S. (eds) Case Studies in e-Government 2.0. Springer, Cham. https://doi.org/10.1007/978-3-319-08081-9_9

7. Akinwunmi, A.O. (2011). New media, political campaigns and violence in Nigeria. Paper presented at the ACCE, Covenant University, Ota. September 2011.

8. Aleyomi, M. B., \& Olanrewaju, O. P. A. (2014). The Impact of Social Media on Citizens' mobilisation and Participation in Nigeria's 2011 General Elections 17(2): 31-52.

9. Anaeto, S., G., Onabanjo, O., S., \& Osifeso, J. (2008). Models and theories of communication.USA; African renaissance book incorporated.

10. Apuke, O. D., \& Tunca, E. A. (2018). Understanding the implications of social media usage in the electoral processes and campaigns in Nigeria. Global Media Journal, 16(31), 1-8. http://www.globalmediajournal. com/archive/gmj-volume-16-issue-31-year-2018.html

11. Arshad, S., \& Khurram, S. (2020). Can government's presence on social media stimulate citizens' online political participation? Investigating the influence of transparency, trust, and responsiveness. Government information quarterly. 37(3). https://doi.org/10.1016/j.giq.2020.101486

12. Bicen, H., \& Cavus, N. (2010). The most preferred social network sites by students. Procedia - Social and Behavioral Sciences, 2(2), 5864-5869. https://doi.org/10.1016/j.sbspro.2010.03.958

13. Bossetta, M. (2018). The digital architectures of Social Media: Comparing political campaigning on Facebook, Twitter, Instagram, and Snapchat in 2016 U.S. Election. Journalism \& Mass Communication Quarterly. 95(2). https://doi.org/10.1177/1077699018763307

14. Boulianne, S. (2019). Revolution in the making? Social media effects across the globe. Information, communication \& society, 22(1), 39-54. https://doi.org/10.1080/1369118X.2017.1353641

15. Cini, M. \& Borragàn, N.P.S. (2010). European Union Politics. Oxford University Press Edn. Claassen, R. L. (2011). Political awareness and electoral campaigns: Maximum effects for Minimum citizens? Political Behavior, 33(2), 203-223. https://doi.org/10.1007/s11109-010-9129-6

16. Ellison, N. B., Steinfield, C., \& Lampe, C. (2007). The benefits of Facebook "friends:" Social capital and college students' use of online social network sites. Journal of Computer-mediated Communication, 12(4), 1143-1168. https://doi.org/10.1111/j.1083-6101.2007.00367.x

17. Eveland, W., P., Hayes, A., F., Shah, D., V., \& Kwak, N. (2005). Understanding the relationship betweencommunication and political knowledge: A model comparison approach using panel data. Political Communication, 22, 423-446. https://doi.org/10.1080/10584600500311345 
18. Freelon, D. (2017). Campaigns in control: Analysing controlled interactivity and message discipline on Facebook. Journal of Information Technology \& Politics, 14(2), $168-181$. https://doi.org/10.1080/19331681.2017.1309309

19. Gerber, A., Green, D., \& Larimer, C. (2010). An experiment testing the relative effectiveness of encouraging voter participation by inducing feelings of pride or shame. Political Behavior, 32, 409-422. https://doi.org/10.1007/s11109-010-9110-4

20. Gibson, R. K., \& McAllister, I. (2012).Online social ties and political engagement. Journal of InformationTechnology \& Politics, 10, 21-34. https://doi.org/10.1080/19331681.2012.712461

21. Gillespie, B., \& Joireman, J. (2016). The role of consumer narrative enjoyment and persuasion awareness in product placement advertising. American Behavioral Scientist, 60(12), 1510-1528. https://doi.org/10.1177/0002764216660136

22. Goh, T-T., Xin, Z., \& Jin, D. (2018). Habit formation in social media consumption: a case of political engagement. Behaviour \& information technology. 38(3). https://doi.org/10.1080/0144929X.2018.1529197

23. Graham, M., \& Avery, E. J. (2013). Government Public Relations and Social Media: An Analysis of the Perceptions and Trends of Social Media Use at the Local Government Level. Public Relations Journal, 7(4).

24. Green, D., \& Gerber, A. (2015). Get out the vote: How to increase voter turnout ( $3^{\text {rd }}$ ed.). Washington, DC: Brookings Institution Press.

25. Groshek, J., \& Koc-Michalska, K. (2017). Helping populism win? Social media use, filter bubbles, and support for populist presidential candidates in the 2016 U.S. election campaign. Information, Communication \& Society, 20(9), 1389-1407. https://doi.org/10.1080/1369118X.2017.1329334

26. Halpern, D., \& Katz, J. E. (2017). We face, I Tweet: How different social media influence political participation through collective and internal efficacy. Journal of Computer-Mediated Communication. 22(6), 320-336 https://doi.org/10.1111/jcc4.12198

27. Hampton, K. N., Shin, I., \& Lu, W. (2017). Social media and political discussion: when online presence silences offline conversation. Information, Communication \& Society, 20(7), 1090-1107. https://doi.org/10.1080/1369118X.2016.1218526

28. Howard, P., N., \& Hussain, M. M. (2013). Democracy's fourth wave?: Digital Media and the Arab Spring. Oxford, U.K.: Oxford University Press. https://doi.org/10.1093/acprof:oso/9780199936953.001.0001

29. Huckfeldt, R., Sprague, J., \& Levine, J. (2000).The dynamic of collective deliberation in the 1996 election: Campaign effects on accessibility, certainty, and accuracy. American Political Science Review, 94, 641- 651. https://doi.org/10.2307/2585836

30. Huckfeldt, R., Mendez, J. M., \& Osborn, T. (2004). Disagreement, ambivalence and engagement: The political consequences of heterogeneous networks. Political Psychology, 25, 65-95. https://doi.org/10.1111/j.14679221.2004.00357.x

31. Ida, R., Saud, M., \& Mashud, M. (2020). An empirical analysis of social media usage, political learning and participation among youth: a comparative study of Indonesia and Pakistan. Qual Quant 54, 1285-1297. https://doi.org/10.1007/s11135-020-00985-9

32. Jacobs, K., \& Spierings, N. (2016). Social media, parties, and political inequalities. Springer. https://doi.org/10.1057/9781137533906

33. Jacobs, K., Sandberg, L., \& Spierings, N. (2020). Twitter and Facebook: Populists' double-barreledgun?. new media \& society, 22(4), 611-633. https://doi.org/10.1177/1461444819893991

34. Joinson A. N. (2008). Looking at, looking up or keeping up with people? Motives and use of facebook. Proceeding CHI '08 of the SIGCHI conference on Human Factors in Computing Systems, pp: 1027-1036. https://doi.org/10.1145/1357054.1357213

35. Jeroense, T., Luimers, J., Jacobs, K., \& Spierings, N. (2021). Political social media use and its linkage to populist and postmaterialist attitudes and vote intention in the Netherlands. European Political Science. https://doi.org/10.1057/s41304-020-00306-6

36. Karakaya, S., \& Glazier, R. A. (2019). Media, information, and political participation: The importance of online news sources in the absence of a free press. Journal of information technology \& politics. 16(3). https://doi.org/10.1080/19331681.2019.1645784

37. Kasadha, J. (2019). Does social media matter in developing democracies? Examining its impact on citizen political participation and expression in Uganda. Journal of public affairs. 20(1). https://doi.org/10.1002/pa.1981

38. Keating, A., \& Melis, G. (2017). Social media and youth political engagement: Preaching to the converted or providing a new voice for youth? The British journal of politics and international Relations. 19(4). https://doi.org/10.1177/1369148117718461

39. Kim, S., \& Lee, J. (2019). Gender and E-Participation in Local Governance: Citizen E-Participation Values and Social Ties. International Journal of Public 1(11). https://doi.org/10.1080/01900692.2019.1575669

40. Kim, Y., \& Chen, H. T. (2016). Social media and online political participation: The mediating role of exposure to cross-cutting and like-minded perspectives. Telematics and Informatics, 33(2),320-330. https://doi.org/10.1016/j.tele.2015.08.008 
41. Kim Y., Chen, H., \& Gil de Zúñiga, H. (2013). Stumbling upon news on the internet: effects of incidental news exposure and relative entertainment use on political engagement. Computers in Human Behavior29(6): 26072614. https://doi.org/10.1016/j.chb.2013.06.005

42. Kreiss, D., \& McGregor, S. C. (2018). Technology firms shape political communication: The work of Microsoft, Facebook, Twitter, and Google with campaigns during the 2016 U.S. presidential cycle. Political Communication, 35(2), 155-177. https://doi.org/10.1080/10584609.2017.1364814

43. Ko, H., Cho, C., H., \& Roberts, M. S. (2005). Internet uses and gratifications: A structural equation model ofinteractive advertising. Journal of advertising 34: 57-70. https://doi.org/10.1080/00913367.2005.10639191

44. Kuehn, S. A. (1994). Computer-Mediated Communication in Instructional Settings: A Research Agenda.Communication Education, 43(2), p171-83. https://doi.org/10.1080/03634529409378974

45. Lappas, G., Triantafillidou, A., \& Kani, A. (2021). Harnessing the power of dialogue: Examining the impact of Facebook content on citizens' engagement. Local Government Studies. https://doi.org/10.1080/03003930.2020.1870958

46. Linde, J., \& Peters, Y. (2020). Responsiveness, support, and responsibility: How democratic responsiveness facilitates responsible government. Party Politics, 26(3), 291-304. https://doi.org/10.1177/1354068818763986

47. Liu, R., Xie, Y., \& Xie, Y. (2017). A study of political participation in new media environment among Chinese citizens. In Y. Xie (Ed.), New media and China's social development (pp. 47-72). Springer Nature.

48. Madueke, O., Nwosu, C., Ogbonnaya, C., \& Anumadu, A. (2017). The Role of Social Media in Enhancing Political Participation in Nigeria. IDOSR Journal of Arts \&Management, 2: 44-54.

49. Mahmud, A., \& Amin, R. (2017). Use of social networking media in political participation: A study on Dhaka university students. Sociology and Anthropology, 5: 481-488. https://doi.org/10.13189/sa.2017.050607

50. Matei, S. A. (2010). What can uses and gratifications theory tell us about social media? Retrieved from https://matei.org/ithink/2010/07/29/what-can-uses-and-gratifications-theory-tell-us-about-social-media/

51. Miller, P. R., Bobkowski, P. S., Maliniak, D., \& Rapoport, R. B. (2015). Talking politics on Facebook: Network centrality and political discussion practices in social media. Political Research Quarterly, 68(2), 377 391. https://doi.org/10.1177/1065912915580135

52. Morris, M. G., \& Venkatesh, V. (2000). Age differences in technology adoption decisions: implications for a changing workforce. Personnel Psychology, 53(2), 375-403. https://doi.org/10.1111/j.17446570.2000.tb00206.x

53. Mousavi, R., \& Gu, B. (2019). The impact of twitter adoption on lawmakers' voting orientations. Information Systems Research, 30(1), 133-153. https://doi.org/10.1287/isre.2018.0791

54. Moy, P., \& Gastil, J. (2006). Predicting deliberative conversation: The impact of discussion networks, media use, and political cognitions. Political Communication, 23: 443-460. https://doi.org/10.1080/10584600600977003

55. Nulty, P., Theocharis, Y., Popa, S. A., Parnet, O., \& Benoit, K. (2016). Social media and political communication in the 2014 elections to the European Parliament. Electoral Studies, 44, 429-444. https://doi.org/10.1016/j.electstud.2016.04.014

56. Ohme, J. (2019). Updating citizenship? The effects of digital media use on citizenship understanding and political participation. Information, communication \& society. 22(13). https://doi.org/10.1080/1369118X.2018.1469657

57. Omotayo, F., O., \& Folorunso, M. B. (2020). Use of social media for political participationby youths. eJournal of eDemocracy and Open Government. 12(1). https://doi.org/10.29379/jedem.v12i1.585

58. Onyechi, N. J. (2018). Taking their destiny in their hands: Social media, youth participation and the 2015 political campaigns in Nigeria. African Journalism Studies, 39(1), 69-89. https://doi.org/10.1080/23743670.2018.1434998

59. Orfan, S. N. (2020). Political participation of Afghan youths on Facebook: A case study of Northeastern Afghanistan, Cogent Social Sciences, 7(1), 1857916, https://doi.org/10.1080/23311886.2020.1857916

60. Papoola, M. (2014). New Media Usage for Communication and Self Concept among Journalism and Mass Communication Students in Oyo State, Nigeria. New Media and Mass Communication, 26: 22-34.

61. Park, N. S., Kee, K. F., \& Valenzuela, S. (2009). Being immersed in social networking environment: Facebook groups, uses and gratifications, and social outcomes. Cyberpsychology \&Behavior, 12: 729-733. https://doi.org/10.1089/cpb.2009.0003

62. Penney, J., \& Dadas, C. (2014). (Re) Tweeting in the service of protest: Digital composition and circulation in the Occupy Wall Street movement. New Media \& Society, 16(1), 74-90. https://doi.org/10.1177/1461444813479593

63. Roy, S. K. (2009). Internet uses and gratifications: A survey in the Indian context. Computers in Human Behavior 25: 878-886. https://doi.org/10.1016/j.chb.2009.03.002

64. Schmiemann, G. N. (2015). Social network sites and political participation: Attributes of the European Union's Facebook pages(B.A. Thesis). University of Twente, Enschede, The Netherlands.

65. Shah, D. V., Cho, J., Eveland, W. P. J., \& Kwak, N. (2005). information and expression in a digital age: Modeling Internet effects on civic participation. Communication Research, 32: 531-565. https://doi.org/10.1177/0093650205279209 
66. Shao, P., \& Wang, Y. (2017). How does social media change Chinese political culture? The formation of fragmentised public sphere. Telematics and Informatics, 34(3), 694-704. https://doi.org/10.1016/j.tele.2016.05.018

67. Sheldon, P. (2008). The relationship between unwillingness to communicate and students' Facebook use. Journal of Media Psychology Theories Methods 20: 67-75. https://doi.org/10.1027/1864-1105.20.2.67

68. Smith, A. (2014). 6 new facts about Facebook. Retrieved from http://www.pewresearch.org/facttank/2014/02/03/6-new-facts-about-facebook/

69. Somaiah, J. (2018). How to Get Out The Vote with Social Media. https://callhub.io/get-out-the-ote-socialmedia/

70. Spierings, N., \& Jacobs, K. (2019). Political parties and social media campaigning. Acta Politica, 54(1), 145173. https://doi.org/10.1057/s41269-018-0079-z

71. Stafford, T., F., \& Gillenson, M. L. (2004). Motivations for Mobile Devices: Uses and Gratifications for MCommerce. SIGHCI 2004 Proceedings. Paper 7. Retrieved 11, April 2012, from http://aisel.aisnet.org/sighci2004/7/

72. Stier, S., Bleier, A., Lietz, H., \& Strohmaier, M. (2018). Election campaigning on social media: Politicians, audiences, and the mediation of political communication on Facebook and Twitter. Political communication, 35(1), 50-74. https://doi.org/10.1080/10584609.2017.1334728

73. Svensson, J. (2011). Power and Participation in Digital Late Modernity: Towards a Network Logic. International Conference in eParticipation. E. Tambouris, A. Macintosh and H. d. Bruijn. Delft, Springer. 3: 109-121. https://doi.org/10.1007/978-3-642-23333-3_10

74. Theunissen, P., \& Noordin, W. N. W. (2012). Revisiting the concept "dialogue" in public relations. Public Relations Review, 38(1), 5-13. https://doi.org/10.1016/j.pubrev.2011.09.006

75. Valenzuela, S., Bachmann, I., \& Bargsted, M. (2019). The Personal Is the Political? What Do WhatsApp Users Share and How It Matters for News Knowledge, Polarization and Participation in Chile.Digital Journalism. https://doi.org/10.1080/21670811.2019.1693904

76. Whiting, A., \& Williams, D. (2013). Why people use social media: a uses and gratifications approach.Qualitative Market Research: An International Journal, 16(4), 362-369. https://doi.org/10.1108/QMR-06-2013-0041

77. Wyer, N. A. (2010). Selective self-categorisation: Meaningful categorisation and the in-group persuasion effect.The Journal of Social Psychology, 150(5), 452-470. https://doi.org/10.1080/00224540903365521

78. Yamamoto, M., Nah, S., \& Bae, S. Y. (2020). Social media prosumption and online political participation: An examination of online communication processes. New Media \& Society, 22(10), 1885-1902. https://doi.org/10.1177/1461444819886295 